$\begin{array}{ll}\text { Abstracta Iranica } & \begin{array}{l}\text { Abstracta Iranica } \\ \text { Revue bibliographique pour le domaine irano-aryen }\end{array} \\ & \text { Volume } \mathbf{3 2 - 3 3} \text { | } \mathbf{2 0 1 3} \\ & \text { Comptes rendus des publications de 2009-2010 }\end{array}$

\title{
Maurizio Pistoso. A Tale of Two Cities. Ahmad Doniš tra Pietroburgo e Bukhara
}

\section{Evelin Grassi}

\section{(2) OpenEdition \\ 1 Journals}

\author{
Electronic version \\ URL: http://journals.openedition.org/abstractairanica/40611 \\ DOI: 10.4000/abstractairanica.40611 \\ ISSN: 1961-960X \\ Publisher: \\ CNRS (UMR 7528 Mondes iraniens et indiens), Éditions de l'IFRI \\ Printed version \\ Date of publication: 1 December 2013 \\ ISSN: 0240-8910

\section{Electronic reference} \\ Evelin Grassi, « Maurizio Pistoso. A Tale of Two Cities. Ahmad Doniš tra Pietroburgo e Bukhara », \\ Abstracta Iranica [Online], Volume 32-33 | 2013, document 265, Online since 01 July 2016, connection \\ on 27 September 2020. URL : http://journals.openedition.org/abstractairanica/40611 ; DOI : https:// \\ doi.org/10.4000/abstractairanica.40611
}

This text was automatically generated on 27 September 2020 .

Tous droits réservés 


\title{
Maurizio Pistoso. A Tale of Two Cities. Ahmad Doniš tra Pietroburgo e Bukhara
}

\author{
Evelin Grassi
}

\section{REFERENCES}

Maurizio Pistoso. «A Tale of Two Cities. Ahmad Doniš tra Pietroburgo e Bukhara », in : Daniele Cevenini and Svevo D’Onofrio, eds., ‘Uyūn al-Akhbār. Studi sul mondo islamico. Collana del Dipartimento di Studi Linguistici e Orientali dell'Università degli Studi di Bologna, Bologna, I libri di Emil, 2010, p. 163-177.

1 This article is devoted to the Bukharan intellectual and man of letters Ahmad Donish [Ahmad-e Dāneš] (1826/7-1897), who is commonly regarded as the leading figure in the Tajik Enlightenment. The "Introduction" on his life and works, with a few linguistic considerations concerning his writings in prose, is followed by an annotated translation in Italian of two sections of Donish's major, partly authobiographical, treatise: Navodir-ul-vaqoe (Navāder al-vaqāyec) [Rare Events]. The first translated section is an extract describing Donish's journey to Saint Petersburg during the winter of 1873 and his reflexions on the meaning and difficulties of traveling abroad. The second section, set in Bukhara, is an entertaining passage from the chapter "Dar Odobi nikoh va bayoni khosumati modarshū" ["Marriage ethics and elucidations on the inconvenience caused by the mother-in-law"]. Saint Petersburg and Bukhara are the main cities in the life of Ahmad Donish. The central Asian Persian Enlightenment was, in part, influenced by the Russian Enlightenment; it is evinced above all in Donish's prose-writings in which the history of the Bukhara Emirate is one of the major subjects. 


\section{AUTHORS}

EVELIN GRASSI

Université de Naples 